\title{
School-Based Physical Activity and the Implementation Paradox
}

\author{
Thomas Skovgaard1,2, Danielle Louise Nørager Johansen ${ }^{1,2}$ \\ ${ }^{1}$ Department of Sport Science and Clinical Biomechanics, University of Southern Denmark, Odense, Denmark \\ ${ }^{2}$ Research and Implementation Centre for Human Movement and Learning, Odense, Denmark \\ Email: tskovgaard@health.sdu.dk
}

How to cite this paper: Skovgaard, T., \& Johansen, D. L. N. (2020). School-Based Physical Activity and the Implementation Paradox. Advances in Physical Education, 10, 492-506.

https://doi.org/10.4236/ape.2020.104038

Received: September 17, 2020

Accepted: November 27, 2020

Published: November 30, 2020

Copyright $\odot 2020$ by author(s) and Scientific Research Publishing Inc. This work is licensed under the Creative Commons Attribution International License (CC BY 4.0).

http://creativecommons.org/licenses/by/4.0/

\begin{abstract}
The purpose of this article is to explore core aspects of implementation management and what implementation management entails within the area of school-based physical activity. The article reports on a comprehensive national Delphi study identifying factors of key importance for implementing school-based physical activity. The Delphi study consisted of four phases: 1) Identifying implementation factors related to school-based physical activity reported in the scientific and grey literature; 2) Requesting a total of 65 national area experts to assess and prioritize the identified factors; 3 ) Interviewing selected national area experts to examine outlier responses; 4) Establishing final consensus on the prioritization of implementation factors identified, ranked and assessed in phase II. In the Delphi study, School management stands out as the factor that overall is considered most essential for successful implementation. The broader research literature on school-based implementation processes confirms the key role that, not least, first-level management, e.g. in the form of a given school's local management, plays in the further deployment of educational policy changes. To put the findings from the Delphi study into perspective, the article discusses central issues on management of organizational implementation-including current knowledge about change and transformation management. In addition, research specifically dealing with strategic processes related to school-based physical activity is included. Finally, the article delivers core messages on what it takes to succeed with implementation management of school-based physical activity initiatives.
\end{abstract}

\section{Keywords}

Implementation, Delphi-Study, Management, Primary and Lower Secondary School, Physical Activity 


\section{A National School Reform-Political Ideals versus Actual Realization}

As part of the latest Danish public school reform in 2014, it was, for the first time, made a requirement for the country's primary and lower secondary schools to incorporate a minimum of 45 minutes of school-based physical activity (PA) for all pupils per day. One of the main drivers of this development was to promote pupils' well-being and support learning through a physically active school day-including activities both inside and outside the classroom (Skovgaard, 2016). Despite this significant policy development, and broad consensus among all key stakeholders that physical activity can contribute to the learning, well-being, and health of children and young people, it is far from all schools that have succeeded with ensuring a school day with a strong focus on physical activity. The latest national survey, conducted five years after the reform, shows that only 55 percent of Danish schools provide the required minimum of 45 minutes of PA per day. This is actually the lowest compliance rate in the four years this item has been surveyed systematically. To state the obvious: The implementation of the political ideal concerning Active Schools is lacking (Jensen et al., 2020; Jensen \& Nielsen, 2018; Nielsen, 2020). On this basis, we, in this article, investigate to what degree and in what ways implementation management plays a role in this type of organizational process. One basic point of departure is to consider management and leadership not as opposites but instead as two synergetic components of the same types of human activities. We use management as the recurring term, with reference to Canadian scientist, Henry Mintzberg-one of the key management researchers of his generation-who views leadership as management practiced well (Mintzberg, 2011).

\section{Implementation of School-Based Physical Activity}

A standard lexical definition of the term "implementation" reads as follows: "The process of putting a decision or plan into effect" (Oxford Dictionary, 2020). The word originates from the Latin "impleo", meaning to complete, fill up, or enrich something (Lewis, 1890). Implementation is, thus, about changing the status quo for-hopefully-the better (for one or more stakeholders). As Fixsen, Blasé and Van Dyke put it: "Fundamentally, implementation is synonymous with change" (Fixen et al., 2019). The analytical starting point of this article is to consider implementation processes as a sequence of events that begin immediately after a decision has been made to change something (e.g. a given practice or behavior); and continues until the decision has been fully implemented or rejected. In short, implementation is the process that lies between an authoritative decision (e.g. in the form of new legislation or programs setting out political principles) and the implementation thereof.

An obvious example may be the decision that something must be done about physical inactivity among pupils attending primary and lower secondary school. The implementation phase begins when the objective is translated into concrete 
initiatives (e.g. the requirement for 45 minutes of movement during the school day) and ends after the organization and implementation of initiatives that can be assessed against relevant performance goals and effects. This somewhat linear understanding of implementation processes is, first and foremost, analytical. In practice, there is a fair amount of back-and-forthing between the often many links from decision to action to complete implementation. Nevertheless, it makes sense to view implementation as a progressive process that-in a more or less controlled and intentional manner-brings about changes in the existing process. Implementation is therefore about conscious developments, in which new practices over time are put into practice in order to achieve stated objectives.

\section{Implementation of School-Based Physical Activity and the Importance of Management}

In a recent research report, based on a comprehensive Delphi study, we identified factors of key importance for implementing school-based physical activity (Johansen et al., 2018). The study is part of a series of publications named "Physical activity and sedentary behavior in school-aged children" (Johansen et al., 2018; Møller et al., 2019).

The Delphi study consisted of four phases:

In Phase I, relevant literature was identified and reviewed in order to point out important implementation factors related to school-based physical activity. A scoping review design was used. Compared to a full systematic review, the scoping review goes less into depth with the assessments of methods, results and conclusions for each publication collected. This method is, however, more rigid than an informal, non-comprehensive literature search. The scoping review makes it possible for a solid overview to be obtained relatively quickly in terms of best available knowledge in a specific area-in this case: Implementation of school-based physical activity. Various thematizations with reference to the core topic (e.g. school, intervention, physical activity, implementation, and children) were plotted into a prepared search matrix, after which keywords and synonyms relating to the overall themes were generated. The matrix subsequently formed the basis for a literature search in the following databases: Scopus, Academic Search Premier, socINDEX and PubMed, which collectively contain a significant amount of the health and social science research literature registered in the field. 3,339 articles were identified in the databases searched. The number of articles was reduced to 31 after the elimination of duplicates and on the basis of stated inclusion and exclusion criteria, e.g.: the studies should take place in primary and lower secondary school contexts; physical activity should be the focal point of the intervention; and implementation should be a key focus of the study, meaning that the study in question was focused on relevant stages of implementation and not only described what a given intervention looked like and contained at the end. Subsequently, databases linked to central national and international entities, namely the Danish Ministry of Children and Education; The Da- 
nish Health Authority; Local Government Denmark (KL), an association of the 98 Danish municipalities; The Danish Institute for Sports Studies (Idan); Danish School Sports; The Danish Center for Social Science Research (VIVE) and The British National Institute for Health and Care Excellence (NICE), was used to search relevant grey literature from home and abroad (cf. Figure 1).

A total of 59 publications from both the grey and scientific literature were finally included for complete review. Based on this, the implementation factors identified were divided into the following categories:

1) The political level referring to formalized structures, legislation and regulations under which a school operates.

2) The organizational level referring to each school's method for setting frameworks and implementing initiatives concerning physical activity.

3) The resource level addressing factors such as working hours, finances and resources needed to make school-based physical activity initiatives work and succeed in practice.

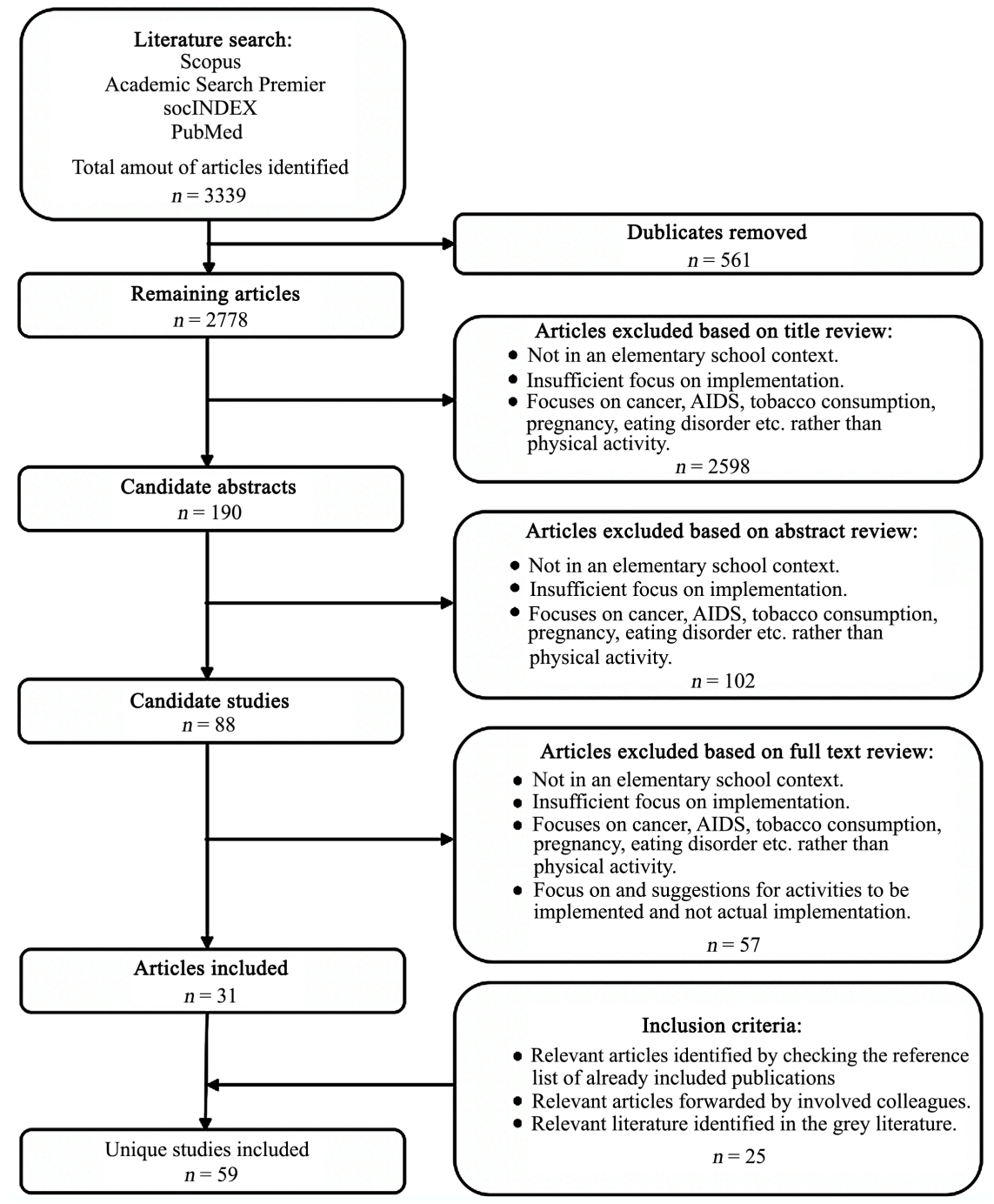

Figure 1. Flow-chart of identified articles for the Delphi study. 
4) The physical framework referring to indoor and outdoor facilities that allow for physical activity at school.

5) The management level defined as the school's management and its role in relation to physical activity at school.

6) The staff level addressing factors concerning the prerequisites and competencies of teachers and educators in being able to implement new practices in relation to physical activity at school in general and in teaching specifically.

7) The pupil level addressing the attitudes, behaviors, involvement and participation of the pupils in the development and implementation of initiatives aimed at physical activity in school.

The original Delphi study included two additional categories, which together sought to identify the importance of intervention characteristics (e.g. primary goals and outcome measures of a given intervention together with mandatory activities embedded in the intervention), wider school context factors (e.g. local/community prioritization of physical activity and health promotion) and other components of possible relevance for the implementation of school-based physical activity. In the end, these broad-spectrum categories proved to be of minor importance.

In Phase II, the identified implementation factors were consolidated into a survey and circulated to a total of 65 national area experts who were asked to assess and prioritize the individual factors. The experts consisted of social educators (in Danish called pedagogues), schoolteachers, school managers, municipal actors (e.g. consultants/advisers, administrative and office managers), as well as organizational actors-e.g. actors from Danish School Sports and major sports associations in Denmark catering, among others, to children and youth. The area experts were identified using a snowball sampling method, prescribing that investigators initially identify respondents with special knowledge related to the subject area through network contacts. These respondents complete the survey themselves and at the same time provide information about potential additional respondents. A saturation point is reached when the same proposals for supplementary respondents are repeated. In this way the probability of involving the most qualified respondents increases. The final sample of 65 national area experts were recruited by the authors and collaborating colleagues through both research and practice networks with the aim of including respondents with current practice experience in the field of school-based physical activity. Of the 65 national area experts, 56 (86\%) responded to the survey.

In phase III, five area experts were invited to elaborate on their survey responses via a semi-structured interview. These experts were selected because their responses differed from the general tendencies of the survey responses.

In phase $I V$, all 56 area experts responding to the survey in Phase $I I$ were invited to participate in a workshop in order to reach consensus on a prioritization of the implementation factors that were identified, ranked and assessed in phase II. In total, 19 (34\%) area experts took part in the workshop (Johansen et al., 2018). 
Across phases I - IV of the Delphi study, School management emerges as the factor that is considered most essential for successful implementation. The broader research literature on school-based implementation processes also draws attention to the key role that management, e.g. in the form of a given school's local management, plays in the further deployment of educational policy changes. In general, the evidence supports the claim that effective school management requires both the abilities to and interest in facilitating distributed and even shared leadership in connection with organizational implementation initiatives (Leithwood et al., 2020; Shapiro et al., 2020).

\section{Implementation Management-In Three Parts}

The remainder of this article, therefore, focuses on what constitutes good implementation management and what implementation management involves within the area of school-based physical activity. The starting point is literature on management of organizational implementation-including current knowledge about change and transformation management. In addition, research specifically dealing with strategic processes related to school-based physical activity is included.

The first part of the article contains a clarification of the management concept and-more interestingly - the uniqueness of implementation management.

The second part of the article draws from the basic assumption that the quality of organizational implementation work-including school-based physical activity-is conditional upon the involved actors having an interest in acting in ways that facilitate the process. This interest is best cultivated by giving as many as possible the capacity to act, as well as control and shared ownership of key decisions.

The third and final part starts by highlighting three aspects-meaningful communication, present employee-manager relationships, and long-term strategies for school-based physical activity—that play a vital role in the quality of implementation work. The article concludes with core messages on what it takes to succeed with implementation management of school-based physical activity initiatives.

\subsection{Part One: Management}

Management is a dynamic pursuit, oftentimes times centered around creating cohesion and prioritizing between a number of framework conditions and relationships. Framework conditions may concern laws and regulations, professional standards, collective agreements, outcome targets of departments and formulated core values of organizations, as well as financial room for maneuver. Relationships may be linked to collaborations with other management levels, executive boards, colleagues and staff teams or key user-citizen groups.

The degree of dynamics does not diminish when dealing with intricate implementation processes that are not successful before the core elements are rec- 
ognized, known, understood, accepted and shared at all levels of the organization.

Therefore, the basic premise of this article is that good management is characterized by a holistic approach to converting the organization's visions and strategies into concrete actions. It is also necessary to respect that a variety of interests need to find each other in sustainable solutions. In this way, maximum followership for the basic idea and the set objectives can be created. This requires managers who are not only able to plan and make decisions but also have the skills to inspire and unlock creativity.

American organizational scholar, Mary Jo Hatch, argues that good management is conditional upon the proficiency to combine rational planning with the ability to inspire and enhance the development of new and dynamic solutions. This package of competencies should not only be in place at the senior management level, but also characterize every part of the organization's managerial system-both formal and informal (Hatch, 2018).

Another prominent American organizational researcher, Frank J. Barrett, goes one step further and sees the ability to improvise-understood as the competence to continually, and without major preparation, create new approaches and processes - as being absolutely central for today's managers (Barrett, 2012). Again, this perspective is particularly important for good implementation management, where the full realization of organizational change projects amongst other is conditional upon the capacity and possibility for different management layers to combine clear objectives and frameworks with room for spontaneity and a common ambition to play off well against each other.

According to already mentioned Henry Mintzberg management is not so much a science or a profession as a practice learned through experience and shaped by the circumstances (actual or imagined) that are currently applicable. According to Mintzberg, management therefore is created in an interaction between three elements that he terms: Art, Craft and Science (Mintzberg, 2011; Mintzbeg, 2013).

The Art element contributes ideas, vision and creativity to management. The Craft element is about the experiences, as well as concrete actions and methods that are important for setting the direction of the overall management practice. The Science element contributes systematic and analytical strength to the management process (Mintzberg, 2011).

In the Delphi study described earlier, we found that the management element across the five area expert groups of educators, school teachers, school managers, municipal and organizational actors was rated the most important overall factor for implementation of school-based physical activity interventions. It is, however, worthwhile to take a closer look at the five experts groups responses respectively.

Table 1 shows that municipal and organizational actors assigned the management element the highest score while ranking the importance of staff 
Table 1. Implementation factors-ranked by five groups of area experts.

\begin{tabular}{|c|c|c|c|c|c|c|}
\hline Rank & $\begin{array}{l}\text { Organizational } \\
\text { actors } \\
(\mathrm{n}=9)\end{array}$ & $\begin{array}{l}\text { Municipality } \\
\text { actors } \\
(n=26)\end{array}$ & $\begin{array}{c}\text { School } \\
\text { managers } \\
(\mathrm{n}=8)\end{array}$ & $\begin{array}{l}\text { School } \\
\text { teachers } \\
(n=10)\end{array}$ & $\begin{array}{l}\text { Educators } \\
\quad(\mathrm{n}=3)\end{array}$ & $\begin{array}{c}\text { Total } \\
(n=56)\end{array}$ \\
\hline 1 & Management & Management & Staff & Staff & Staff & Management \\
\hline 2 & Staff & Staff & Management & Resources & Management & Staff \\
\hline 3 & Resources & Policy & Pupils & $\begin{array}{l}\text { Physical } \\
\text { framework }\end{array}$ & Pupils & Resources \\
\hline 4 & Pupils & Organization & $\begin{array}{l}\text { Physical } \\
\text { framework }\end{array}$ & Pupils & $\begin{array}{l}\text { Physical } \\
\text { framework }\end{array}$ & Policy \\
\hline 5 & Policy & Resources & $\begin{array}{l}\text { Intervention } \\
\text { characteristic }^{\star}\end{array}$ & Management & Resources & Organization \\
\hline 6 & Organization & $\begin{array}{l}\text { Intervention } \\
\text { characteristic }\end{array}$ & Resources & Organization & Organization & Pupils \\
\hline 7 & $\begin{array}{l}\text { Physical } \\
\text { framework }\end{array}$ & $\begin{array}{l}\text { Physical } \\
\text { framework }\end{array}$ & External $^{\star}$ & Policy & $\begin{array}{l}\text { Intervention } \\
\text { characteristic }\end{array}$ & $\begin{array}{l}\text { Physical } \\
\text { framework }\end{array}$ \\
\hline 8 & $\begin{array}{l}\text { Intervention } \\
\text { characteristic }^{*}\end{array}$ & Pupils & Organization & $\begin{array}{c}\text { Intervention } \\
\text { characteristic }\end{array}$ & Policy & $\begin{array}{c}\text { Intervention } \\
\text { characteristic }\end{array}$ \\
\hline 9 & External $^{*}$ & External ${ }^{*}$ & Policy & External ${ }^{*}$ & External ${ }^{*}$ & External ${ }^{*}$ \\
\hline
\end{tabular}

${ }^{*}$ Not addressed further in this article c.f. the elaboration and explanation of categories in Section 4.

(schoolteachers and educators) in second place. By comparison, the group of school managers and educators rate the staff as the most important implementation factor, while management is weighted as the second most important. The expert group consisting of schoolteachers rates the management as being of only medium importance for the implementation process. According to the teachers, the most important factors for successful implementation of school-based physical activity are concentrated around the professional staff having the proper prerequisites to drive the change forward. These prerequisites consist of having sufficient time to develop and achieve the task, as well as adequate physical frameworks, in the form of indoor and outdoor facilities, that contribute to this. Interestingly, only school managers and educators include The pupil level as a top-three implementation factor. All respondents, however, recognize pupils' overall support to adoption of new practice as crucial (Johansen et al., 2018).

Whether the low level of priority given to the management factor by the expert group consisting of schoolteachers in the Delphi study is due to the fact that the surveyed teachers have had to deal with managers struggling with establishing followership and development for new initiatives and practices, which, according to Hatch, are essential for good management; coming up short with initiating the organizational improvisations looked for by Barrett; or not being able to build up sufficient practical knowledge as a manager-an important perspective for Mintzberg-is not possible to provide a definitive judgment of. Still, the marked low rating by teachers of the importance of management is, in itself, worth mentioning. Literature, from various areas of health and physical 
activity research, highlights first-level managers, in particular, as key implementation actors, whose task it is to create coherence and prioritize in situations where consensus about what exactly should be done many times is only partial and the need to secure a co-operative implementation environment is essential (e.g. Birken et al., 2016; Gutberg \& Berta, 2017; Garne-Dalgaard et al., 2019; Skage \& Dyrstad, 2019). The teachers' creative solutions regarding, for instance, movement at school are promoted by a management that is able to create useful framework conditions for those who will ultimately implement the ambitions decided.

\subsection{Part Two: Involvement Promotes the Quality of Implementation}

The second part of the article is based on the point that: The quality of implementation efforts is subject to the actors involved having an interest in acting in ways that promote the process. The literature concerning organizational-based implementation often emphasizes widespread involvement of relevant stakeholders as an essential element in creating real and sustainable change (Muellmann et al., 2017; Dennis et al., 2015). Thus, it is an important management task to promote dialog and involvement-amongst others to avoid "collective silence" where no one says anything: either because they are indifferent or lack commitment, or because managers are seen as controlling and unilaterally decisive.

Good implementation management is therefore about creating attractive communities that appeals positively to the parties involved and make them feel engaged in the objectives of the organization. Whether, how, and when the individual employee is ready and willing for this is ultimately an individual concern. In this respect, effective management (by an individual or a team) is the one who has, and is capable of expressing, empathy and providing a high degree of managerial attendance and presence with a focus on making it clear to, e.g. employees, how their efforts play a role and should be measured on the basis of the overall effort of the organization. These are different competences from that of the classic functions such as operational, professional and/or strategic manager. Personal management is brought to the foreground, and the focus is moved to building and maintaining common understandings and recognition of the strategy's potential at both the individual and the collective level. As management researcher Herminia Ibarra points out the competent (implementation) manager combines three basic components: Strong communication of a principal idea (to compare with a vision), effective and often multifaceted involvement processes and active use of his or her self in the role of a manager who inspires and motivates followership of important decisions (Ibarra, 2015).

In Leading Change (2012), John P. Kotter (a central figure in the field of leadership and change) points out that the best performance in relation to organizational changes (e.g. in the form of organizational implementation) is achieved 
by providing constant specific feedback on progress and possible errors in order to achieve concrete and challenging objectives. Through Kotter, we learn that the achievement of long-term ideal objectives like, for instance, physical activity for all grades and in all subjects is, most definitely, crucial. But a number of visible milestones should be established from which the quality of the preliminary efforts can be assessed. Firstly, because it makes it possible to adjust what may be necessary. Secondly, and this is key in this context, because milestones in the form of ambitions in the short and medium term allow for an objective-based discussion of the process so far and a cause for celebrating the "small" victories (Kotter, 2012).

Danish management consultant and author, Bo Vestergaard, points out something similar in his compressed presentation on change management and strategy execution, Fair Process, when he states that it is crucial for process participants to make frequent progress in meaningful collaboration and experience what is known as Agency: The ability to do something useful with/in the situation (Vestergaard, 2019). Vestergaard, therefore, emphasizes one of the basic messages of this article in a slightly different way: Good implementation management is very much about building a sense of meaningfulness and capacity to act in relation to the new, and thereby provide a sense of positive progress. It is necessary for managers who fit into that reality to involve stakeholders in dialog and problem-solving aimed at the needs and strategic choices of the organization.

In continuation of the point that the degree of implementation is conditional upon stakeholder interest in acting on methods that promote the process, the Delphi study on implementation of school-based physical activity in Denmark highlights an important relationship regarding the primary areas of responsibility for various parties. The political level (in this case e.g. understood as the municipality council) is, by the Danish Public School Law, committed to the overall operation and development of local public schools. The school managers are responsible for the quality of teaching based on the same body of law. It is therefore the municipality council who sets out the ways in which a school is to run, while school manager coordinates the framework for the concrete implementation of legislation-e.g. the requirement of 45 minutes daily physical activity. Another essential group is the learning staff, which mainly consists of teachers and educators. They are responsible for the actual implementation in relation to those who it is all about: The pupils. The implementation capacity and willingness of teachers and educators will typically require focused support from, in particular, first-level management-in the form of school management. Depending on the size and scope of the implementation, there may, for example, be a need for a competence boost in order to accommodate new tasks. It is also important that management levels build a common and shared understanding of the framework and intended results of the implementation process. In such connections, it is central that there is maximum specification of expectations 
and aspirations for employees' execution (Johansen et al., 2018).

\subsection{Part Three: Communication and Presence}

As previously announced, the third and final part of the article is based on three aspects that, in the literature, typically are highlighted as playing a vital role in the quality of implementation efforts.

\subsubsection{Meaningful Communication}

The significance of clear and consistent communication can hardly be exaggerated in connection with efforts to disseminate knowledge, create understanding and commitment to organizational implementation. As already pointed out, communication should be conducted meaningfully-involving target-specific and well-timed statements concerning what the implementation consists of, why it is needed and what consequences it is expected to have at individual and collective levels (Nielsen et al., 2018). Experience shows that if the rationale for new strategy lines are clearly formulated and substantiated, and as long as the speed of implementation is not too excessive and includes reasonable possibilities to contribute with input, most stakeholders have no major qualms about accepting and following the process (see Cameron \& Green, 2015 for a general discussion of this and other topics related to change management).

\subsubsection{Employee-Manager Relationships Focusing on Community Creation}

Active employee influence on as large a part of the implementation process as possible is a positive motivational factor that can be usefully brought into play. This point is also underlined in the Delphi study, where a particularly clear conclusion is that management must focus on prioritizing and supporting the desired initiatives, thereby motivating the learning staff to drive the change forward. Delegating responsibilities to employee groups, who have particular knowledge and know-how, is cited as a distinctive suitable method. This may include the school's physical education teacher group, who possesses specialized knowledge about movement and physical activity in relation to children and youth. The experience of co-ownership, as well as early and consistent involvement, contributes to an increase in the employee's recognition of the qualities of, and perhaps even the need for, organizational implementation (Johansen et al., 2018). At the same time, it is a managerial task to continually find the right balance between, on the one hand, challenges faced by employees and, on the other hand, experiences and resources that can be offered. The fact remains that the benefits of employee participation in exploring where the new challenges are, and developing solution models for this purpose, more than outweigh the potential disadvantages involved (Gray et al., 2019; The SURE Collaboration, 2011).

In other words: Effective implementation management cannot take place from a distance. On the contrary, it is centered on creating focal points and presence. It is from this premise that managers must take action and know that the difficulty rarely lies in creating change under specific circumstances, but rather to 
maintain what, for one reason or another, is perceived as improved practice when the nitty-gritty of everyday life comes around.

\subsubsection{Long-Term Strategies for School-Based Physical Activity}

Sustainable implementation and anchoring of physical activity as an active part of the school's everyday practice requires the change not only to be maintained but also strengthened along the way. Again, it is crucial that management adhere to the change-e.g. by repeated "participation" and outwardly making clear that this is the right path to take and, above all, clarifying how working with physical activity is important for the ambitions and core tasks of the school. Along the same lines, it is equally important that management makes all employees see how physical activity makes sense for them and their work effort-even if they are not necessarily always close to the area. It is therefore crucial that awareness for the school's work with physical activity as an area for learning and activity is raised on a constant basis. It is not enough that the area "simply" exists (e.g. as part of a legal text that may appear rather abstract).

Success for the long-term anchorage of physical activity as part of general school practice is conditional upon the parties involved having the necessary resources and commitment to address and implement this area. Strategic use of physical activity in schools cannot be operated as a minor development project, as it requires agile adaptation of the overall development, strategic ambitions and tactical maneuvers of the organization. A truly implementable initiative must be whole-hearted and based on the supportive energy that exists within the people involved.

\section{Finishing Up: Management Is Necessary}

Implementation of school-based physical activity works best when first-level management assumes clear responsibility for creating frameworks and conditions that promote, in particular, employee opportunities and incentives to engage in ensuring this during the school day. In this regard, good implementation management starts with building a common professional mindset that has an effect on the level where it really counts-in this case: for the individual pupil.

This point also stands out in the national Delphi study, which concludes that managers who are not only able to prioritize, plan, coordinate and make decisions but also inspire and generate creativity and imagination are required (Johansen et al., 2018). This statement aligns well with Mary Jo Hatch's assertion that good management consists of an effective interaction between acting as a challenging catalyst for development and the solid guarantor of a well-functioning work environment. In this regard, it is about being able to act as the organizational improviser, as looked for by Barrett, and possess the capacity to carry out the vision and lead the way, which according to Mintzberg constitutes an important indication of management. At the same time, specific divisions of tasks and essential operational matters must be addressed, optimal development of the competences of employees and the various professional teams ensured and usa- 
ble models must be built for managing the conflicts and/or disputes that are a necessary and welcome part of any organizational implementation process.

It takes time before the organization-e.g. the individual school or an entire school district-reaps the rewards of focusing more on, for instance, physical activity. It is therefore essential that managers-not least managers of individual schools and/or district managers-employees and other core stakeholders put a shared strategy for the area into words and set ambitious goals, which are also realistic to achieve in the foreseeable future.

If the managements involved are successful with these kinds of change tasks, the opportunities to reap the full benefits of the joint strategic work on physical activity as part of the school's daily work will increase-in ways that make sense for policymakers, managers, teachers and educators and, hugely important, among the pupils involved.

To sum up: By promoting shared decision making involving the whole school organization, securing frequent and targeted communication that positions physical activity as an important element in realizing the school's strategic goals and continuously supporting key stakeholders' (e.g. learning staff) capacity to act, school management plays a fundamental role in successful implementation of school-based physical activity.

\section{Acknowledgements}

The authors sincerely appreciate the contributions of Professor Jens Troelsen, Active Living research-unit, Department of Sports Science and Clinical Biomechanics, University of Southern Denmark and Associate professor Niels Christian Møller, Research Unit for Exercise Epidemiology, University of Southern Denmark as co-authors of the national Delphi study.

\section{Conflicts of Interest}

The authors declare no conflicts of interest regarding the publication of this paper.

\section{References}

Barrett, F. J. (2012). Yes to the Mess: Surprising Leadership Lessons from Jazz. Brighton, MA: Harvard Business Review Press.

Birken, S. A., DiMartino, L. D., Kirk, M. A., Shoou-Yih, D. L., McClelland, M., \& Albert, N. M. (2015). Elaborating on Theory with Middle Managers' Experience Implementing Healthcare Innovations in Practice. Implementation Science, 11, Article No.: 2. https://doi.org/10.1186/s13012-015-0362-6

Cameron, E., \& Green, M. (2015). Making Sense of Change Management: A Complete Guide to the Models, Tools and Techniques of Organizational Change (4th ed.). London: Kogan Page Publishers.

Dennis, S., Hetherington, S. A., Borodzicz, J. A., Hermiz, O., \& Zwar, N. A. (2015). Challenges to Establishing Successful Partnerships in Community Health Promotion Programs: Local Experiences from the National Implementation of Healthy Eating Activity and Lifestyle $\left(\mathrm{HEAL}^{\mathrm{Tm}}\right.$ ) Program. Physical Activity and Diet, 26, 45-51. 
https://doi.org/10.1071/HE14035

Fixsen, D. L., Blasé, K. A., \& Van Dyke, M. K. (2019). Implementation Practice and Science. Independently Published.

Garne-Dalgaard, A., Mann, S., Bredahl, T. V. G., \& Stochkendahl, M. J. (2019). Implementation Strategies, and Barriers and Facilitators for Implementation of Physical Activity at Work: A Scoping Review. Chiropractic \& Manual Therapies, 27, Article No.: 48. https://doi.org/10.1186/s12998-019-0268-5

Gray, P., Senabe, S., Naicker, N., Kgalamono, S., Yassi, A., \& Spiegel, J. M. (2019). Workplace-Based Organizational Interventions Promoting Mental Health and Happiness among Healthcare Workers: A Realist Review. International Journal of Environmental Research and Public Health, 16, 4396. https://doi.org/10.3390/ijerph16224396

Gutberg, J., \& Berta, W. (2017). Understanding Middle Managers' Influence in Implementing Patient Safety Culture. BMC Health Services Research, 17, Article No.: 582. https://doi.org/10.1186/s12913-017-2533-4

Hatch, M. J. (2018). Organization Theory-Modern, Symbolic, and Postmodern Perspectives. Oxford: Oxford University Press.

Ibarra, H. (2015). Act Like a Leader, Think Like a Leader. Boston, New York: Harvard Business School Publishing.

Jensen, V. M., \& Nielsen, C. P. (2018). Viden om Folkeskolereformen-Opsamling af resultater fra følgeforskningsprogrammet 2015-2018. Copenhagen: VIVE-The Danish Center for Social Science Research.

Jensen, V. M., Bjørnholt, B., Mikkelsen, M. F., Nielsen, C. P., \& Lasekjær E. (2020). Den længere og mere varierede skoledag-En analyse af reformens elementer. Copenhagen: VIVE-The Danish Center for Social Science Research.

Johansen, D. L. N., Møller, N. C., Troelsen, J., \& Skovgaard, T. (2018). At sætte børn i bevægelse fra viden til handling-Implementering af skolebeaseret fysisk aktivitet. Research and Implementation Centre for Human Movement and Learning, Odense: University of Southern Denmark and UCL University College.

Kotter, J. P. (2012). Leading Change. Brighton, MA: Harvard Business Review Press.

Leithwood, K., Harris, A., \& Hopkins, D. (2020). Seven Strong Claims about Successful School Leadership Revisited. School Leadership \& Management, 40, 5-22. https://doi.org/10.1080/13632434.2019.1596077

Lewis, T. C. (1890). An Elementary Latin Dictionary. New York, Cincinnati, Chicago: American Book Company.

http://www.perseus.tufts.edu/hopper/text?doc=Perseus:text:1999.04.0060:entry=impleo

Mintzberg, H. (2011). Managing. San Francisco, CA: Berrett-Koehler Publishers.

Mintzberg, H. (2013). Simply Managing: What Managers Do-and Can Do Better. San Francisco, CA: Berrett-Koehler Publishers.

Møller, N. C., Pedersen, J., Rasmussen, M. G., \& Østergaard, L. (2019). At sætte børn i bevægelse fra viden til handling-fysisk aktivitetsinterventioner $i$ skolen. Research Unit for Exercise Epidemiology and Centre of Research in Childhood Health, Odense: University of Southern Denmark.

Muellmann, S., Steenbock, B., De Cocker, K., De Craemer, M., Hayes, C., O’Shea, M. P., Horodyska, K., Bell, J., Luszczynska, A., Roos, G., Langøien, L. J., Rugseth, G., Terragni, L., De Bourdeaudhuij, I., Brug, J., \& Pischke, P. R. (2017). Views of Policy Makers and Health Promotion Professionals on Factors Facilitating Implementation and Maintenance of Interventions and Policies Promoting Physical Activity and Healthy Eating: Results of the DEDIPAC Project. BMC Public Health, 17, Article No.: 932. 
https://doi.org/10.1186/s12889-017-4929-9

Nielsen, J. H. (2020). Bevægelse i Skoledagen 2020. Danish School Sports, Nyborg, Denmark.

Nielsen, J. V., Klakk, H., Bugge, A., Andreasen, M. L., \& Skovgaard, T. (2018). Implementation of Triple the Time Spent on Physical Education in Pre-School to 6th Grade: A Qualitative Study from the Programme Managers' Perspective. Evaluation and Program Planning, 70, 51-60. https://doi.org/10.1016/j.evalprogplan.2018.06.001

Oxford Dictionary (2020). Meaning of Implementation in English. https://en.oxforddictionaries.com/definition/implementation

Shapiro, V. B., Ziemer, K. L., Accomazzo, S., \& Kim, B. K. E. (2020). Teachers' Assessment of "Implementation Leadership" during a New Social Emotional Learning Initiative. Contemporary School Psychology, 24, 174-180.

https://doi.org/10.1007/s40688-019-00230-7

Skage, I., \& Dyrstad, S. M. (2019). “It's Not Because We Don't Believe in It...”: Headteachers' Perceptions of Implementing Physically Active Lessons in School. BMC Public Health, 19, Article No.: 1674. https://doi.org/10.1186/s12889-019-8021-5

Skovgaard, T. (2016). Sport in Danish Schools: physical activity and public policy formulation in Denmark. International Journal of Sport and Society, 7, 13-27. https://doi.org/10.18848/2152-7857/CGP/v07i01/13-27

The SURE Collaboration (2011). SURE Guides for Preparing and Using Evidence-Based Policy Briefs: 5. Identifying and Addressing Barriers to Implementing Policy Options. Version 2.1 [updated November 2011].

Vestergaard, B. (2019). Fair proces-Fra upopulære forandringer til medarbejdere, der udvikler løsninger (2nd ed.). Denmark: LEAD READ. 